\title{
NYCTEREUTES TEMMINCK, 1838 (MAMMALIA, CANIDAE): A REVISION OF THE GENUS ACROSS THE OLD WORLD DURING PLIO-PLEISTOCENE TIMES
}

\author{
Saverio Bartolini Lucenti 10 \\ Dottorato di Ricerca in Scienze della Terra, Università di Pisa, Via S. Maria 53, 56126 Pisa, Italy; saverio.bartolini@dst.unipi.it \\ Dipartimento di Scienze della Terra, Università degli Studi di Firenze 50121, Italy.
}

\author{
KEYWORDS: \\ Raccoon-dogs; \\ State of art; \\ Pliocene; \\ Biogeography; \\ Canidae.
}

\section{Bullet-Points Abstract}

- Although Nyctereutes is nowadays monospecific, the fossil record suggests a larger diversity and wider distribution.

- The study of large sample from numerous sites of the Old World allowed a critical revision at an intercontinental scale.

- Some specimens of Layna and the sample from Çalta reveal peculiar morphologies, contrasting with the attribution to $N$. donnezani.

- The peculiarities of two samples testify to the urge for new research on fossil Nyctereutes.

\section{INTRODUCTION}

Nyctereutes Temminck, 1838 is nowadays represented by the single species Nyctereutes procyonoides (Gray, 1834). This taxon inhabits two separated areas of Eurasia (Ward \& Wurster-Hill, 1990): a natural one (spanning from the Eastern part of Russia, China, Korean peninsula and Japan) and an artificial one resulted from the accidental or intentional introduction during the 1920s and 1930s across Eastern and Central Europe (from Finland to Hungary and from France to the Caucasus). On the contrary, the fossil record reveals a much greater diversity as up to 10 species have been described in literature (Bates, 1937; Rook et al., 2017). Furthermore, the fossil distribution range was not limited to Eurasia since Nyctereutes spp. were recovered also from several regions of Africa (see among others Werdelin \& Dehghani, 2011).

The dentognatic features possessed by $N$. procyonoides are diagnostic for the genus and, at least part of them, were acquired by the extant raccoon-dogs' ancestors as the result of progressive adaptations towards a hypocarnivorous diet. Among these characteristics, there are the reduction of slicing portions of the carnassials and enlargement of the crushing surface of the molars, the developed subangular lobe, the expansion of the angular process, and the development of the insertion areas of the muscle pterigoideus medialis, on the medial side of the mandible.

Thanks to a considerably large sample from more than twenty-five sites across the Old World, this study combines the summary of the state of art of the past research on the genus Nyctereutes together with the most recent findings in the Old World.

\section{Materials ANd Methods}

The fossil sample studied for this research comes from numerous Eurasian and African localities, housed in several institutions (See Table 1). The considered species are Nyctereutes abdeslami Geraads, 1997, ?Nyctereutes barryi Werdelin \& Dehghani, 2011, Nyctereutes donnezani (Depéret, 1890), Nyctereutes megamastoides (Pomel, 1842), Nyctereutes sinensis (Schlosser, 1903), Nyctereutes tingi Tedford \& Qiu, 1991, Nyctereutes terblanchei Ficcarelli et al., 1984, Nyctereutes vulpinus Soria and Aguirre, 1976. The extant comparative sample includes specimens of $N$. procyonoides, Vulpes vulpes (Linnaeus, 1758), Vulpes lagopus (Linnaeus, 1758) and Cerdocyon thous Smith, 1839 housed in the MZUF and AMNH (See abbreviation below).

\section{Institutional abbreviations}

AMNH, American Museum of Natural History, New York (U. S. A.); AUT, Aristotle University Thessaloniki (Greece); GNM, Georgian National Museum, Tbilisi (Georgia); IGF, Geological and Paleontological Section of the Natural History Museum of the University of Florence; MdC, Musée des Confluences, Lyon (France); MNCN, Museo Nacional de Ciencias Naturales, Madrid (Spain); MNHN, Musée National d'Histoire Naturelle, Paris (France); MZUF, La Specola, Zoological section of the Natural History Museum of the University of Florence; UCBL-1,Université Claude-Bernard Lyon-1, Lyon (France).

\section{Discussions}

The Old world record of Nyctereutes: an update

The earliest occurrences of the genus is in the Yushe 


\begin{tabular}{|c|c|c|}
\hline Species & Locality & Repository \\
\hline N. tingi & $\begin{array}{l}\text { Yushe Basin (Liujiagou, } \\
\text { Nanzhuanggou) (China); } \\
\text { Megalo Emvolon (Greece) }\end{array}$ & AMNH \\
\hline N. sinensis & $\begin{array}{l}\text { Yushe Basin (Beihai, } \\
\text { Liujiagou, Xiachuang, } \\
\text { Zhangwagou, Zha- } \\
\text { ozhuan), Nihewan Basin } \\
\text { (China) }\end{array}$ & $\begin{array}{l}\text { AMNH, } \\
\text { MNHN }\end{array}$ \\
\hline N. donnezani & $\begin{array}{l}\text { Perpignan-Roussillon } \\
\text { (France); Layna, La Gloria } \\
4^{*} \text { (Spain) }\end{array}$ & $\begin{array}{l}\text { AMNH, } \\
\text { MdC, MNCN, } \\
\text { UCBL-1 }\end{array}$ \\
\hline N. vulpinus & St. Vallier (France) & Mdc, UCBL-1 \\
\hline N. megamastoides & $\begin{array}{l}\text { Senéze, Perrier-L'Etouaires } \\
\text { (France); Kvabebi (Geor- } \\
\text { gia); Dafnero (Greece); } \\
\text { Csarnota, Beremend } \\
\text { (Hungary); Montopoli, S. } \\
\text { Giusto (Italy); El Rincon, } \\
\text { Villarroya (Spain) }\end{array}$ & $\begin{array}{l}\text { AUT, GNM, } \\
\text { HMNH, } \\
\text { IGF, MNCN, } \\
\text { MNHN, } \\
\text { UCBL-1 }\end{array}$ \\
\hline N. abdeslami & $\begin{array}{l}\text { Ahl al Oughlam } \\
\text { (Morocco) }\end{array}$ & MNHN \\
\hline N. terblanchei & $\begin{array}{l}\text { Kroomdrai A* } \\
\text { (South Africa) }\end{array}$ & IGF \\
\hline$? N$. barryi & $\begin{array}{l}\text { Upper Laetoli Bed* } \\
\text { (Tanzania) }\end{array}$ & MNHN \\
\hline Nyctereutes sp. & Çalta (Turkey) & MNHN \\
\hline
\end{tabular}

Tab. 1. List of the considered sample for this study: the species of Nyctereutes, the localities where they come from and the institutions in which they are housed in.

basin (China, MN14-15, Tedford et al., 2013) with the primitive species $N$. tingi (Fig. 1A). Its morphologies strongly differ from all the other Nyctereutes spp. for the modest or scarce development of mandibular and dental features (as pointed out by Tedford \& Qiu, 1991).Around 4-3.5 Ma, there is a first burst in diversity (Fig. 1B): i) firstly, the African record starts at this time with the dubious and primitive ?N. barryi from the Upper Laetoli Bed (Tanzania); ii) secondly, the occurrence of $N$. sinensis, in the same Chinese basin of $N$. tingi, which marks the appearance of a taxon that resembles the extant $N$. procyonoides for the degree of developmente of its dentognatic features. Then in Western Europe, $N$. donnezani was described from French and Spanish sites. Some authors deem that this first European species corresponds to $N$. tingi (see Tedford \& Qiu, 1991). In contrast to the Asian record (see Tedfor et al., 2013), during the late Pliocene in Europe, primitive and derived forms of raccoon-dogs never coexisted: $N$. donnezani was replaced by $N$. megamastoides.

A second burst is dated between 3.5-2 Ma (Fig. 1C). N. megamastoides appears in Europe at this time (Bartolini Lucenti, 2017), and, partially due to its large range of distribution (from Spain to Georgia, Rook et al., 2017), it is one the most renowned fossil species of this genus. The retention of strongly derived dental and cranio-mandibular features in N. megamastoides, led some scholars to suggest the idea that this taxon and $N$. sinensis are closely related (Soria \& Aguirre, 1976), although some morphological differences remain (Rook et al., 2017). The sample from St. Vallier (France), historically attributed to N. megamastoides (Viret, 1954; Martin, 1971) should be classified as a separate taxon from N. megamastoides and in this respect, for the presence of some features resembling the genus Vulpes, (Soria \& Aguirre, 1976) suggested for this remains the attribution to the species $N$. vulpinus. Apart from the controversial taxon ?N. barryi, the African record of Nyctereutes is relatively scanty but diverse. Younger although still early Pliocene in age, the primitive Nyctereutes lockwoodi Geraads et al., 2010 from Dikika (Ethiopia) shows several peculiar morphologies, which justify the separation in a different species. Other findings in Africa are the Early Pleistocene $N$. abdeslami from Morocco, and the South African N. terblanchei (both derived species).

After $2 \mathrm{Ma}$, and during the last part of the Early Pleistocene, the findings of Nyctereutes across the whole Old World become more and more scarce and the diversity of the genus declined. The first record of the extant $N$. procyonoides appears in Middle Pleistocene deposits of China (Zhoukoudian 1 and 13, Tedford \& Qiu, 1991) and remained the only species of the genus until today, with the exception of the Palestinian Nyctereutes vinetorum Bates, 1937 (which may simply represent a larger form of the extant species).

\section{The record of Layna and Çalta}

The ongoing revision of the material from two important localities referred to MN15 (Layna, Spain; Çalta, Turkey) yielded some unexpected results. In literature, these samples are referred to $N$. donnezani (Soria \& Aguirre, 1976; Ginsburg, 1998). Nevertheless, at Layna few specimens show morphological similarities and morphometric proportions that cannot be explained as intraspecific variability, as they suggests affinity with derived forms. The Nyctereutes from Çalta possesses an undeniable primitive-like morphology of the mandible corpus with a reduced subangular lobe (as noted by Ginsburg, 1998) albeit its dental proportions or the shape of the molars (especially upper ones) does not fit with the attribution to $N$. donnezani. On the contrary, the dental characters showed by the Çalta Nyctereutes are close to those of forms like $N$. sinensis, $N$. vulpinus or, even more, $N$. megamastoides.

\section{Conclusions}

The fossil record of the genus Nyctereutes, spanning in whole Old World in the last $5 \mathrm{Ma}$, testifies to a great variety in morphologies and adaptations in diet. Many scholars have investigated the evolutionary history of this genus, yet many issues are still matters of debate and fertile grounds for research (e.g., the phylogenetic relationships between the species). This short overview of Nyctereutes spp. summarizes our current know- 


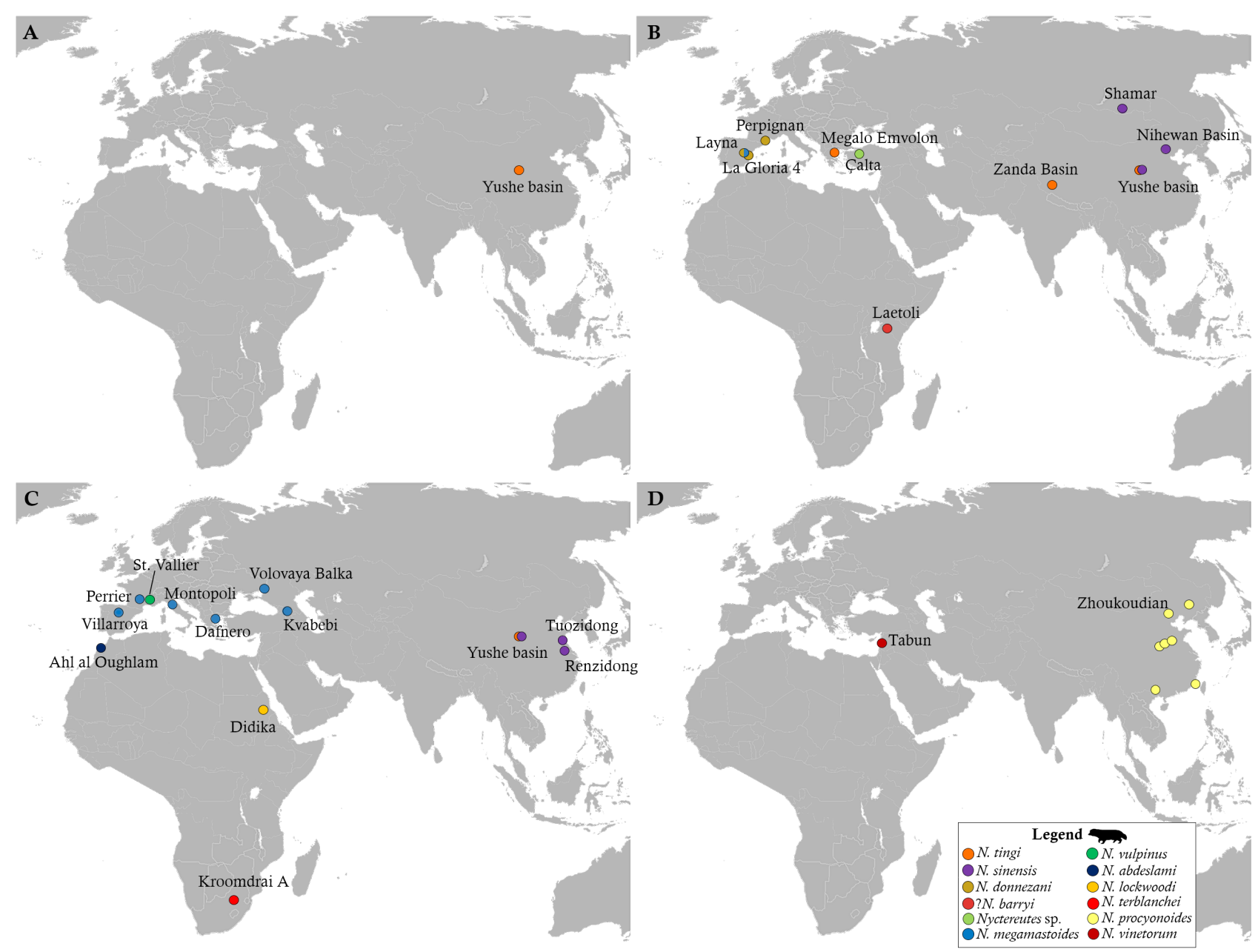

Fig. 1. Geographic and temporal distribution of Nyctereutes spp. from the earliest Early Pliocene to present times across the Old World. A, earliest Early Pliocene, 5.3-4.5 Ma. B, Early-Late Pliocene, 4.5-3.5 Ma. C, Latest Pliocene-Early Pleistocene (partim), 3.5-1.5 Ma. D, Middle Pleistocene-Present times, 800-0 ka.

ledge of their diversity and evolutionary history, and points out peculiar two cases (i.e. those of Layna and Çalta), which certainly require deep studies in the future. Should the hypothesis of an early appearance of form with mixed pattern of morphologies in the MN15 be validated, it could reveal the presence in the Early Pliocene of an alternative lineage of raccoon-dogs, with serious implications on Nyctereutes dispersion and evolution across the Palearctic, the Afrotropical and the Indomalayan regions.

\section{ACKNOWLEDGEMENTS}

The author is thankful to the kindness and availability of E. Cioppi (IGF), P. Agnelli (MZUF), M. Bukhsianidze (GNM), E. Robert (UCBL-1), D. Berthet (MdC), J. Galkin and J. Meng (AMNH), M. Gasparik (HMNH), C. Argot (MNHN), $\mathrm{S}$. Fraile $(\mathrm{MNCN})$, and G. Koufos (AUT). This research has been partly supported by the SYNTHESYS Project http:// www.synthesys.info/ (Project Numbers ES-TAF-6553, HUTAF-6520), which is financed by European Community Research Infrastructure Action under the FP7 "Capacities" Program.

\section{REFERENCES}

Bartolini Lucenti S. (2017). Nyctereutes megamastoides (Canidae, Mammalia) from the early and middle Villafranchian (late Pliocene and early Pleistocene) of the Lower Valdarno (Firenze and Pisa, Tuscany, Italy). Rivista Italiana di Paleontologia e Stratigrafia, 123: 211-218.

Bates D. M. A. (1937). Palaeontology: The fossil fauna of the Wady el-Mughara caves. In The Stone Age of Mount Carmel. Excavations at the Wady El-Mughara. Oxford (Clarendon Press), vol. 1, part 2: 137-233.

Depéret C. (1890). Les Animaux Pliocènes du Roussillon. Mémoires de la Societé Géologique de France, 3: 5-195.

Ficcarelli G., Torre D. \& Turner A. (1984). First evidence for a species of raccoon dog, Nyctereutes Temminck, 1838, in South African Plio-Pleistocene deposits. Boll. Soc. Paleont. It., 23: 125-130.

Geraads D. (1997). Carnivores du Pliocène terminal de Ahl al Oughlam (Casablanca, Maroc). Géobios, 30: 127- 164.

Geraads D., Alemseged Z., Bobe R. \& Reed D. (2010). Nyctereutes lockwoodi, $\mathrm{n}$. sp., a new canid (Carnivora: Mammalia) from the middle Pliocene of Dikika, Lower Awash, Ethiopia. Journal of Vertebrate Paleontology, 30: 981-987.

Ginsburg L. (1998). Le gisement de vertébrés pliocènes de Çalta, Ankara, Turquie. 5. Carnivores. Geodiversitas, 20, 379-396. 
Gray J. (1834). Illustration of Indian zoology, consisting of coloured plates of new or hitherto unfigured Indian animals from the collection of Major General Hardwicke. Fol, London 2: pI. 1.

Linnaeus C. (1758) - Systema Naturae per regna tria naturae, secundum Classes, Ordines, Genera, Species, cum characteribus, differentiis, synonymis, locis. Tomus I, 10th edition: Holmiae, Laurentius Salvius, Stockholm, Sweden, $824 \mathrm{p}$.

Martin R. (1971). Les affinités de Nyctereutes megamastoides (Pomel), canidé du gisement villa franchien de Saint-Vallier (Drôme, France). Palaeovertebrata, 4: 39-58.

Pomel M. (1842). Nouvelle espèce de chien fossile découverte dans les alluvions volcaniques de l'Auvergne. Bulletin de la Société Géologique de France,14: 38-41.

Rook L., Bartolini Lucenti S., Bukhsianidze M. \& Lordikipanidze D. (2017). The Kvabebi Canidae record revisited (late Pliocene, Sighnaghi, eastern Georgia). Journal of Paleontology, 91: 1258-1271.

Schlosser M. (1903). Die fossilen Säugethiere Chinas nebst einer Odontographie de recenten Antilopen. Abhandlungen der Mathematisch-Physikalischen Klasse der Königlich Bayerischen Akademie der Wissenschaften, 22: 1-220.

Smith C. H. (1839). The Canine Family in general or the genus Canis. In W. Jardine (ed), The naturalist's library, vol. 18. Natural history of dogs, vol. 1. Edinburgh: W. H. Lizars, 267 pp.

Soria D. \& Aguirre E. (1976). El cánido de Layna: revisión de los Nyctereutes fósiles. Trabajos Neógeno y Cuaternario, 5: 83-115.

Tedford R. H. \& Qiu Z. (1991). Pliocene Nyctereutes (Carnivora: Canidae) from Yushe, Shanxi, with comments on Chinese fossil raccoon-dogs. Vertebrata PalAsiatica, 29: 176-189.

Tedford R. H., Qiu Z. X. \& Flynn L. J., eds. (2013). Late Cenozoic Yushe Basin, Shanxi Province, China: Geology and Fossil Mammals. Springer, New York.

Temminck C. (1838). Over de kennis en de Verbreiding der Zoogdieren van Japan. Tijdschrift Natuurlijke Geschiedeins en Physiologie, 5: 273- 293.

Viret J. (1954). Le loess à bancs durcis de Saint-Vallier (Drôme) et sa faune de mammifères villafranchiens: Nouveau Archives du Musee d'Histoire Naturelle de Lyon, 4: $1-200$.

Ward O. G. \& Wurster-Hill D. H. (1990). Nyctereutes procyonoides. Mammalian Species, 358, 1-5.

Werdelin L. \& Dehghani R. (2011). Carnivora. In Harrison T. (ed.) Geology and Paleontology of Laetoli: Human evolution in context. Springer, New York: 189-232.

\author{
Manuscript received 15 July 2018 \\ Received after revision 14 September 2018 \\ Accepted 20 September 2018
}

